\title{
RBP4 wt Allele
}

National Cancer Institute

\section{Source}

National Cancer Institute. RBP4 wt Allele. NCI Thesaurus. Code C138097.

Human RBP4 wild-type allele is located in the vicinity of $10 \mathrm{q} 23.33$ and is approximately 10 $\mathrm{kb}$ in length. This allele, which encodes retinol-binding protein 4, is involved in the transport of retinol. Mutation of the gene is associated with both isolated microphthalmia with coloboma and retinal dystrophy, iris coloboma and comedogenic acne syndrome. 